Research.

\title{
Analysis of the effects of earnings ratio per share, price earnings and return on equity ratio upon the change of shares price at PT. Telekomunikasi Indonesia Tbk years of 2008 - 2017
}

\author{
Dimas Ari Darmantyo \\ Department of Management, Economic College of Binaniaga, Bogor, Indonesia \\ Shelva Kalay Shelwin \\ Department of Management, Economic College of Binaniaga, Bogor, Indonesia
}

\begin{abstract}
Received: August 27, 2019; Accepted: October 12, 2019; Published: December 31, 2019
To cite this article: Darmantyo, Dimas Ari, Shelva Kalay Shelwin. 2019. Analysis of The Effects of Earnings Ratio Per Share, Price Earnings and Return on Equity Ratio upon The Change of Shares Price at PT.

Telekomunikasi Indonesia Tbk. Years of 2008-2017. The Management Journal of BINANIAGA. 4 (2): 11-20. doi: $10.33062 / \mathrm{mjb} . v 4 \mathrm{i} 2.332$
\end{abstract}

\begin{abstract}
This research has tested some financial ratios of Earning Per Share, Price Earning Ratio and Return On Equity upon the Change of Shares Price at telecommunication company sector for the period of 2008 to 2017 to know the significance of those ratios, so that, it can be used by the investors to make a decision before investing their money. By having Time Series data of 2008 - 2017, this research has found out that the variables of Earning Per Shares (EPS) and Price Earning Ratio (PER) have significantly affected the change of shares price, but Return On Equity (ROE) has not significantly affected it. This research has indicated that the three independent variables (EPS, PER and ROE) have significantly affected shares price change.
\end{abstract}

Keywords: Finance Ratio, Return On Equity, Earning Per Share, Price Earning Ratio and price of shares

\section{Introduction}

\section{Background of the Research}

Investment is a profitable business but a high risk, so that it requires a careful analysis and consideration before making a decision to deal with the investment. Shares investment as one of investment businesses which is quite an interesting one, though it is a high risk investment. Shares is as a proof of company's ownership that can give them profit such as devident and gain capital.

Finance Ratio is an analysis tool used in shares investment. Some Finance Ratios being used to analyze are as follows: Return On Equity (ROE) is to measure to the extent of which profit will be owned by the shareholders.

Earning per share (EPS) is the most important component to be considered in analyzing a company (Tandelilin, 2010:373) Bigger EPS has indicated bigger company efforts to gain net profit for shareholders, so that, it could increase the price of share.

Another finance ratio that affecting the shares is Price Earning Ratio (PER) which describing the comparison between Market Price Per Shares (price of a share in stock market) and earning per share (profit per a share)

Dimas Ari Darmantyo and Shelva Kalay Shelwin. Analysis of The Effects of Earnings Ratio Per Share, Price Earnings and Return on Equity Ratio upon The Change of Shares Price at PT. Telekomunikasi Indonesia Tbk. Years of 2008 - 2017 
The companies which are being used as the objects of this research are Telecomunication Corporations for the period of 2008 - 2017. In accordance with the background description above, a research should have to be done to prove that finance ratios(EPS, PER, and ROE) have been affecting the price of shares.

According to the aforementioned perception, the writer has decided to use the title of: "Analysis the effects of earning per share ratio, price earning ratio and return on equity upon the change of share price at PT. Telekomunikasi Indonesia Tbk. (Indonesian telecomunication Itd) periode 2008-2017".

\section{Aims of The Research}

Aims of the research to be achieved are as follows:

1. To identify the effect of Earning Per Share (EPS) upon the change of share price at PT Telekomunikasi Indonesia, Tbk, for the period of $2008-2017$.

2. To identify the effect of Price Earning Ratio (PER) upon the change of share price at PT Telekomunikasi Indonesia, Tbk, for the period of $2008-2017$.

3. To identify the effect of Return On Equity $(\mathrm{ROE})$ upon the change of share price at PT Telekomunikasi Indonesia, Tbk, for the period of $2008-2017$.

4. To identify the effect of Earning Per Share (EPS), Price Earning Ratio (PER) and Return On Equity (ROE) upon the change of share price at PT Telekomunikasi Indonesia, Tbk, for the period of 2008-2017.

\section{Library Review}

\section{Return On Equity (ROE)}

Munawir (2010:240) defined that Return On Equity is a ratio between net profit after tax and company shares indicating the productivity of company shareholder. This ratio has indicated profitability and efficiency of company shares.

Sartono (2009:131) defined the following ROE equation:

$$
\text { Return On Equity }=\underset{\text { Shares of the company }}{\text { Net profit after tax }}
$$

\section{Earning Per Share (EPS)}

Kashmir (2016:115) described that Earning Per Share is a ratio measuring the shares. Low ratio has explained that the management has not satisfied yet the shareholders, and high ratio indicating that the company has satisfied the shareholders by providing big returns.

Tandelilin (2010:374) described the following EPS equation:

$$
\text { Earning Per Share }=\text { Total of the shares circulated }
$$

\section{Per Earning Ratio (PER)}

Price Earning Ratio (PER) is an indicator which is mostly being used to examine the price of share. The higher the value of the shares, the lower the PER will be. Actually, the investors will buy the shares having low PER since they are expecting to have faster cash flow. Price Earning Ratio has been describing market appreciation upon the company providing profit. PER has indicated to the extent of which the stockmarket has appreciated the future prospect of a company (Sartono, 2009:124).

Dimas Ari Darmantyo and Shelva Kalay Shelwin. Analysis of The Effects of Earnings Ratio Per Share, Price Earnings and Return on Equity Ratio upon The Change of Shares Price at PT. Telekomunikasi Indonesia Tbk. Years of 2008 - 2017 
PER Equation is as the following:

Price Earning Ratio $=$ Market price per share

Net profit per share

\section{Share}

Darmadji \& Fachrudin (2012:5) describing that shares are a legal proof of someone ownership or a legal institution ownership upon a certain company or a limited company defining which portion of ownership is designed based on the total shares they invested. Shares are one of security papers that mostly marketed in the stockmarket. As a matter of fact, nowadays, many emitents have registered their shares in the stockmarket.

\section{Price of the Share}

Darmadji \& Fachrudin (2012:102), defined that price of shares is the price in the stockmarket at a certain time which can increase or decrease very fast within a minute or even in a second. It could happen due to the offer and demand happened between shares buyer and shares seller.

\section{Research Design}

H1 : The effect of Return On Equity (ROE) has happened upon the price of share.

H2 : The effect of Earning Per Share (EPS) has happened upon the price of share.

H3 ; The effect of Price Earning Ratio (PER) has happened upon the price of share.

$\mathrm{H} 4$; The effects of Return On Equity (ROE), Earning Per Share (EPS), Price Earning Ratio (PER) have happened upon the price of share.

\section{Method of The Research}

\section{Type of the Research Method.}

This research can be classified as quantitative research that requires a lot of numbers, starting from data collection, perception of those data and the result. However, to understand and to conclude the research, it will be better using table, graph, chart and drawing. Besides of using numbers, this research has also applied qualitative information which is the effect of company characterization upon social and environment appeared in the telecommunication corporations listed in the Indonesia Stock Exchange.

\section{Variable of the Research and its Measuring}

Table.

Operational Variable

\begin{tabular}{|c|c|c|c|}
\hline Variable & Function & Indicator & $\begin{array}{c}\text { Scale/ } \\
\text { Measurement }\end{array}$ \\
\hline Market Price & EPS & EPS & Ratio \\
\hline Market Price & PER & PER & Ratio \\
\hline Profitability & ROE & ROE & Ratio \\
\hline $\begin{array}{c}\text { Change of Share } \\
\text { Price }\end{array}$ & $\begin{array}{c}\text { CHANGE } \\
\text { PRICE OF } \\
\text { SHARES }\end{array}$ & $\begin{array}{c}\text { Price of share } \\
\text { (Closing Price) }\end{array}$ & Ratio \\
\hline
\end{tabular}

Dimas Ari Darmantyo and Shelva Kalay Shelwin. Analysis of The Effects of Earnings Ratio Per Share, Price Earnings and Return on Equity Ratio upon The Change of Shares Price at PT. Telekomunikasi Indonesia Tbk. Years of 2008 - 2017 


\section{Population and Sample}

Population of this research are Telecomunication Companies listed in Indonesia Stock Exchange (BEI) and sampling has applied Purposive Sampling Technique. Purposive sampling is a technique to define the samples based on a certain criteria or consideration (Sugiyono, 2012:117). The company being the sample of this research is PT Telekomunikasi Indonesia, Tbk. For the period of 2008 up to 2017.

\section{Data Collection Method.}

Data collection has applied documentary method which is data collection using secondary data. Secondary data is refered to the information collected by other people who have been doing an updated study instead of the researcher(Ghozali, 2011:65). This research used yearly finance report data of PT Telekomunikasi Indonesia, Tbs period of $2008-2017$ that had been got from legal website of Indonesia Stock exchange which is www.idx.co.id and https://finance.yahoo.com.

\section{Result and Description}

\section{General Information of the Object of the Research}

Object of this research is Telecommunication companies listed on the Indonesia Stock Exchange, PT Telekomunikasi Indonesia, Tbk.

\section{Brief Story of the Company}

Limited Enterprise of PT Telekomunikasi Indonesia, Tbk (Telkom) is BUMN (Business Corporation owned by the government) dealing with telecommunication services and telecommunication networking in Indonesia. Majority of shareholders is owned the government of the Republic of Indonesia and the remaining of shares owned by public. In 1995 an Initial Public Offering (IPO) about Telkom's shares was executed on 14 November 1995. Since 14 November 1995, shares of Telkom have been registered and marketed in the Indonesia Stock Exchange (BEI), New York Stock Exchange (NYSEI), London Stock Exchange (LSE) and Public Offering Without Listing (POWL) in Japan.

\section{Test of Classical Assumption}

Before executing linear regression analysis, classical assumption test has to be done to identify whether or not the data has had normal distribution, autocorrelation matters, multicollinearity and heteroscedasticity.

\section{Normality Test}

This test is to examine whether all the residual value of each variable which has been put into this model have had normal distribution.

Dimas Ari Darmantyo and Shelva Kalay Shelwin. Analysis of The Effects of Earnings Ratio Per Share, Price Earnings and Return on Equity Ratio upon The Change of Shares Price at PT. Telekomunikasi Indonesia Tbk. Years of 2008 - 2017 


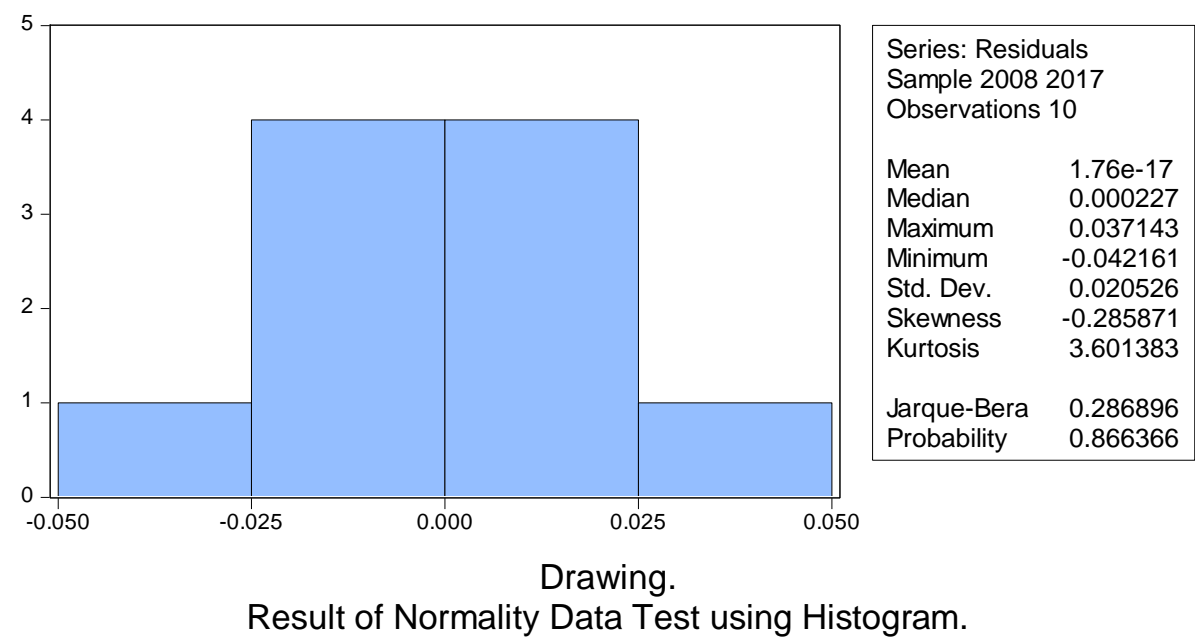

Based on the drawing 1 above, it has indicated Probability Jarque-Bera of $0.866>$ 0.05 , it has explained that the data has normally distributed.

\section{Multicolinearity Test}

Table.

Result of Multicolinearity Test

\begin{tabular}{|c|c|c|c|}
\hline \multicolumn{3}{|c|}{ Variance Inflation Factors } & \\
\hline \multicolumn{4}{|c|}{ Date: 07/27/19 Time: 11:12 } \\
\hline \multicolumn{4}{|c|}{ Sample: 20082017} \\
\hline \multicolumn{4}{|c|}{ Included observations: 10} \\
\hline & Coefficient & Uncentered & Centered \\
\hline Variable & Variance & VIF & VIF \\
\hline $\mathrm{C}$ & 0.003926 & 62.12169 & NA \\
\hline EPS & $1.38 \mathrm{E}-07$ & 46.80956 & 2.829645 \\
\hline PER & $2.07 \mathrm{E}-05$ & 95.47823 & 2.908259 \\
\hline ROE & 0.021958 & 18.26332 & 1.047117 \\
\hline
\end{tabular}

Based on the result of Multicolinearity Test above and in order to examine whether or not multicollinearity has occured in linear regression model, it can be identified by VIF value of each variable. It has indicated that VIF value of ROE variable of 1.047, EPS of 2.829 and PER of 2.908 explaining that VIF values of those three variables are less than or $<10$. Nevertheles, it is concluded that linear regression did not identify any multicollinearity matters.

\section{Heteroscedasticity Test}

Heteroscedasticity test aims to find out whether a regression model has identify varied inequality of residual error of each observation. In order to detect whether herescedasticity is occurred or not, we can use Glejser Rest. Result of heteroscedasticity test is indicated on the table below:

Dimas Ari Darmantyo and Shelva Kalay Shelwin. Analysis of The Effects of Earnings Ratio Per Share, Price Earnings and Return on Equity Ratio upon The Change of Shares Price at PT. Telekomunikasi Indonesia Tbk. Years of $2008-2017$ 
The Management Journal of BINANIAGA Vol. 04, No. 02, December 2019

p-ISSN: 2527 - 4317, e-ISSN: $2580-149 x$

$6^{\text {th }}$ Accreditation Rating: April 04, 2019- April 03, 2024

Table. Test of Heteroscedasticity Test

Heteroskedasticity Test: Glejser

\begin{tabular}{llll}
\hline \hline F-statistic & 3.832138 & Prob. F(3,6) & 0.0760 \\
Obs*R-squared & 6.570726 & Prob. Chi-Square(3) & 0.0869 \\
Scaled explained SS & 5.350631 & Prob. Chi-Square(3) & 0.1479 \\
\hline \hline
\end{tabular}

Test Equation:

Dependent Variable: ARESID

Method: Least Squares

Date: 08/27/19 Time: 11:15

Sample: 20082017

Included observations: 10

\begin{tabular}{crrrr}
\hline \hline Variable & Coefficient & Std. Error & t-Statistic & Prob. \\
\hline \hline C & 0.097656 & 0.025767 & 3.789920 & 0.0091 \\
EPS & 0.000224 & 0.000153 & 1.468866 & 0.1923 \\
PER & -0.005203 & 0.001873 & -2.778351 & 0.0321 \\
ROE & -0.126902 & 0.060940 & -2.082424 & 0.0825 \\
\hline \hline
\end{tabular}

Table 2 above has shown value of Chi-Square Probability of Obs* R-Squared which is more than 0.05 indicating that heteroscedasticity symptom did not occur.

\section{Autocorelation Test}

Table.

Result of Regression Eviews Output

Dependent Variable: LNSAHAM

Method: Least Squares

Date: 07/27/19 Time: 11:11

Sample: 20082017

Included observations: 10

\begin{tabular}{crlll}
\hline \hline \multicolumn{1}{c}{ Variable } & Coefficient & Std. Error & t-Statistic & Prob. \\
\hline CPS & 5.841737 & 0.062657 & 93.23424 & 0.0000 \\
PER & 0.006015 & 0.000371 & 16.19983 & 0.0000 \\
ROE & 0.065499 & 0.004554 & 14.38371 & 0.0000 \\
& -0.286371 & 0.148183 & -1.932553 & 0.1015 \\
\hline \hline R-squared & 0.997555 & Mean dependent var & 7.732189 \\
Adjusted R-squared & 0.996332 & S.D. dependent var & 0.415068 \\
S.E. of regression & 0.025139 & Akaike info criterion & -4.239632 \\
Sum squared resid & 0.003792 & Schwarz criterion & -4.118598 \\
Log likelihood & 25.19816 & Hannan-Quinn criter. & -4.372406 \\
F-statistic & 815.8438 & Durbin-Watson stat & 2.095944 \\
Prob(F-statistic) & 0.000000 & & & \\
\hline \hline
\end{tabular}

Previous autocorrelation test has been done using Durbin Watson (DW) method. Result on table above is indicated Durbin Watson value of 2.095 and this DW value is not within the value of DU of 2.016 and (4-DU) of 1.984, however, DW value is within the value (4-DL) of 3.475 and (4-DU), nevertheless, it has indicated that Durbin Watson is

Dimas Ari Darmantyo and Shelva Kalay Shelwin. Analysis of The Effects of Earnings Ratio Per Share, Price Earnings and Return on Equity Ratio upon The Change of Shares Price at PT. Telekomunikasi Indonesia Tbk. Years of 2008 - 2017 
unable to conclude about autocorrelation circumstance. The researcher has applied furthermore autocorrelation test using Breusch-Godfrey Serial Correlation LM Test.

Table.

Autocorrelation Test

Breusch-Godfrey Serial Correlation LM Test:

\begin{tabular}{llll}
\hline \hline F-statistic & 2.474877 & Prob. F(2,4) & 0.1998 \\
Obs*R-squared & 5.530603 & Prob. Chi-Square(2) & 0.0630 \\
\hline \hline
\end{tabular}

Table above has indicated the value of Chi-Square Probability of Obs* R-Squared of 0.063 which is more than 0.05 . It has indicated that autocorrelation matters did not happen.

\section{Analysis of Correlation and Determinant Coefficient.}

\section{Correlation Coefficient Analysis}

Based on regression analysis, $\mathrm{R}$ value is 0.998 or $99.8 \%$, it explains that the correlation between independent variables (ROE, EPS and PER) with dependent variable (change price of share) is having a strong correlation since the percentage value of $99.8 \%$ which is within 0.800-1.000 (Sugiyono, 2012:214).

\section{Analysis of Determinant Coefficient}

$\mathrm{R} 2$ value or $\mathrm{R}$ square is indicated on Table 3. Result of data processed based on Eviews has indicated $R 2$ value of 0.997 . This value has explained that the role of independent variables (ROE, EPS and PER) upon the variation of dependent varianle (change of shares price) is $99.7 \%$ and the remaining of $0.3 \%$ is influenced by other variables which are not included in the model of the research.

\section{Multiple Linear Regression}

It is a linear correlation between two or more independent variables (EPS, PER, $\mathrm{ROE}$ ) with dependent variable (change of shares price). This analysis is applied to indicate the direction of correlation between independent variables with dependent variable whether each independent variable has a positive or negative correlation with dependent variable. Based on Table 3, a multiple linear regression model equation is designed as the following:

$$
\text { LNSAHAM }=a+b_{1} \text { EPS }+b_{2} P E R+b_{3} R O E
$$

$$
\text { Change price of shares }=5.8417+0.006 E P S+0.0655 P E R-0.2864 R O E
$$

Refers to the linear regression above, it has been describing that:

1) Constant of 5.8417 has explained that if the value of EPS,PER, and ROE value is 0 , and price of share will change $5.8417 \%$

2) Coefficient of regression of EPS variable of 0.006 has indicated that EPS is having positive effect upon price of shares, it means that every increasing of one unit of EPS variable will increase the price of shares of $0.006 \%$ with the assumption that other variables are constant.

3) Coefficient of regression of PER variable of 0.0655 indicating that PER has positive effect upon change of the price of share, it means that every increasing of one unit of PER will increase also the price of share of $0.0655 \%$.

Dimas Ari Darmantyo and Shelva Kalay Shelwin. Analysis of The Effects of Earnings Ratio Per Share, Price Earnings and Return on Equity Ratio upon The Change of Shares Price at PT. Telekomunikasi Indonesia Tbk. Years of 2008 - 2017 
4) Coefficient of regression of ROE variable of -0.2864 indicating that ROE has a negative effect upon change of the share price, it means that every increasing of one unit of ROE will be decreasing the price of share of $0.2864 \%$.

\section{Hypothesis Test}

\section{T-test ( partial)}

T-test is to prove whether independent variable has individually affected dependent variable (Widarjono, 2015:25). Based on the data on Table 3 which is t-test result, it has concluded that:

a) H1 : The effect of Earning Per Share (EPR) upon change of the shares price at Telecommunication companies listed on the Indonesia Stock Exchange.

Test result of Hypothesis $1(\mathrm{H} 1)$ in this research has got sig.value of 0.000 . Because sig.value $=0.00<\alpha=0,05$, nevertheless, $\mathrm{Ha}$ is accepted but $\mathrm{HO}$ is rejected which is indicating that EPS has significantly affected the change of shares price.

b) H2 : The Effect of Earning Ratio (PER) upon the price of shares at Telecommunication companies listed on the Indonesia Stock Exchange.

Test result of Hypthesis $2(\mathrm{H} 2)$ in this research has got sig.value of 0.000 . Because sig.value $=0,000<\alpha=0,05$, nevertheless, $\mathrm{Ha}$ is accepted but $\mathrm{H} 0$ is rejected which is indicating that PER has affected significantly change of the price of shares.

c) H3 : The Effect of Return On Equity (ROE) upon the price of shares at Telecommunication companiens listed on the Indonesia Stock Exchange.

Test result of Hypothesis $3(\mathrm{H} 3)$ in this research is indicating sig.value of 0.000 , and because sig.value $=0,101>\alpha=0,05$, nevertheless $\mathrm{Ha}$ is rejected but $\mathrm{HO}$ is accepted which is indicating that ROE has not significantly affected change of the share price.

\section{F-test (simultant)}

According to the data on Table 3 indicating F-count of 815.843 and sig. of 0.000 , it has explained that due to sig.value $<0.05$, so that, independent variables (EPS, PER and $\mathrm{ROE})$ have significantly affected the price of shares.

\section{Description}

The Effect of Earning Per Share (EPS) upon the change of shares price at the Telecommunication companies listed on the Indonesia Stock Exchange.

Result of the research indicated that EPS affected positively and significantly the change of shares price. Every increasing of EPS would be positively affecting change of share price. This research is getting along with the research done by Wardi (2015) found out that Earning Per Share variable had positively and significantly affected the price of shares at Mining Companies listed on BEI period $2009-2011$.

The Effect of Price Earning Ratio (PER) upon the Change of Price of Shares at Telecommunication companies listed on the Indonesia Stock Exchange.

This research indicated that PER affected significantly the change of share price, it has explained that either low or high value of PER can affect the change of share price. This result is getting along with the research of Risdiyanto \& Suhermin (2016) indicating that variable of PER has significantly affected the price of share.

The Effect of Return On Equity (ROE) upon the change of shares price at Telecomunication Companies listed on the Indonesia Stock Exchange.

This result has defined that ROE did not significalty affect the change of share price. This research has been getting along with the research done by Egam, llat, and Pangerapan (2017) found out that Return On Equity (ROE) did not significantly influence

Dimas Ari Darmantyo and Shelva Kalay Shelwin. Analysis of The Effects of Earnings Ratio Per Share, Price Earnings and Return on Equity Ratio upon The Change of Shares Price at PT. Telekomunikasi Indonesia Tbk. Years of 2008 - 2017 
the price of shares of the companies involved in Index LQ45 at the Indonesia Stock Exchange period 2013 - 2015. However, this research is not getting along with the research of Hadi(2018) found out that ROE had significalty affected the price of shares. It could happened due to the diversified companies selected on the research.

The Effect of Return On Equity (ROE), Earning Per Share (EPS) and Price Earning Ratio (PER) upon the price of shares of the Telecommunication companies listed on the Indonesia Stock Exchange.

The research has indicated that variables of ROE, EPS, and PER have significantly affected the change of share price. This research has been in compliance with the research done by Ratih, Apriatni \& Saryadi (2013) indicated that variables of EPS, PER, DER and ROE had significantly affected the price of shares.

\section{Conclusion and Suggestions}

\section{Conclusion}

Based on the result of analysis and description above regarding Telecommunication companies listed on the Indonesia Stock Exchange about The Effects of Return On Equity (ROE), Earning Per Share (EPS) and Price Earning Ratio (PER) upon the Change of Shares Price for the period of 2008-2017, it is concluded that:

1. EPS variable has positively and significantly affected Change of Shares Price (LNSAHAM) because of its sig.value of 0.000 which is less than 0.05 .

2. PER variable has significantly affected Change of Shares Price (LNSAHAM), because of its sig.value of 0.000 which is less than 0.05 .

3. ROE variable did not affect significantly Change of Shares Price (LNSAHAM) because of its sig.value of 0.101 which is bigger than 0.05 .

4. Simulantneously ROE, EPS and PER variables have significantly affected Change of Shares Price (LNSAHAM), because of its Fcount value of 815.843 and sig. value of 0.000 which is less than 0.005 .

\section{Suggestions}

According to the result of description and conclusions obtained, therefore there are some suggestions offered:

1. The investors should have to be concerned more about ratio of EPS and PER of the company as a consideration tools to make a decision before investing their money.

2. For next researchers, they could involve other variables such as exchange rate gap, government policies and technology innovation instead of financial ratio only.

\section{References}

Bursa Efek Indonesia. 2017. Laporan Keuangan \& Tahunan. TLKM. www.idx.co.id. Diakses pada 12 Desember 2017 pukul 10.00 WIB.

Darmadji, T., \& Fachrudin. (2012). Pasar Modal Di Indonesia. In Salemba Empat (p. 14).

Egam, G. E. Y., llat, V., \& Pangerapan, S. (2017). Pengaruh Return On Asset (ROA), Return On Equity (ROE), Net Profit Margin (NPM), dan Earning Per Share (EPS) terhadap Harga Saham Perusahaan yang tergabung dalam LQ45 DI BURSA EFEK INDONESIA PERIODE TAHUN 2013 - 2015. Jurnal EMBA, Vol 5(No. 1), 105-114.

Ghozali, I. (2011). Aplikasi Analisis Multivariate dengan menggunakan SPSS. In Gramedia.

Dimas Ari Darmantyo and Shelva Kalay Shelwin. Analysis of The Effects of Earnings Ratio Per Share, Price Earnings and Return on Equity Ratio upon The Change of Shares Price at PT. Telekomunikasi Indonesia Tbk. Years of 2008 - 2017 
Hadi, W. (2018). Analysis of The Effect of Net Profit Margin, Return on Assets and Return on Equity on Stock Price (Case Study on Consumption Industrial Sector Companies Listed in Indonesian Sharia Stock Index at Indonesia Stock Exchange in 2016). The Management Journal of Binaniaga, 3(2), 81. https://doi.org/10.33062/mjb.v3i2.261.

Kasmir. (2016). Pengantar Manajemen Keuangan (2nd ed.). Jakarta: Kencana Prenada Media Group.

Munawir. (2010). Analisa Laporan Keuangan Edisi 4. In Jakarta: Salemba Empat.

Ratih, D., Apriatni, \& Saryadi. (2013). Pengaruh EPS, PER, DER, ROE Terhadap Harga Saham pada Perusahaan Sektor Pertambangan yang Terdaftar di Bursa Efek Indonesia (BEI) Tahun 2010-2012. Diponegoro Journal of Social and Politic, 1-12.

Risdiyanto, \& Suhermin. (2016). Pengaruh ROI, EPS, dan PER Terhadap Return Saham pada Perusahaan Farmasi. Jurnal IImu Dan Riset Manajemen, 5(7), 0-15.

Sartono, A. (2009). Manajemen Keuangan:Teori dan Aplikasi (4th ed.). Yogyakarta: BPFE Yogyakarta.

Sugiyono. (2012). Metode Penelitian Kuantitatif, Kualitatif dan R \& D.Bandung:Alfabeta. Metode Penelitian Kuantitatif, Kualitatif Dan $R$ \& D.Bandung:Alfabeta. https://doi.org/10.1017/CBO9781107415324.004.

Tandelilin, E. (2010). Portofolio dan Investasi Teori dan Aplikasi. Yogyakarta: Kanisius, 1-387. https://doi.org/10.2753/MIS0742-1222260306.

Wardi, J. (2015). Pengaruh Current Ratio, Debt to Equity Ratio, Return on Equity dan Earning Per Share terhadap Harga Saham pada Perusahaan Pertambangan yang Terdaftar di BEI Periode 2009-2011. Jurnal Akuntansi, 3(2), 127-147.

Widarjono, A. (2015). Analisis Multivariat Terapan (2nd ed.). Yogyakarta: UPP STIM YKPN.

Yahoo Finance. Perusahaan Perseroan (Persero) PT. Telekomunikasi Indonesia. (TLKM.JK). www.finance.yahoo.com. Diakses pada 12 Desember 2017 pukul 12:00 WIB.

Dimas Ari Darmantyo and Shelva Kalay Shelwin. Analysis of The Effects of Earnings Ratio Per Share, Price Earnings and Return on Equity Ratio upon The Change of Shares Price at PT. Telekomunikasi Indonesia Tbk. Years of 2008 - 2017 